
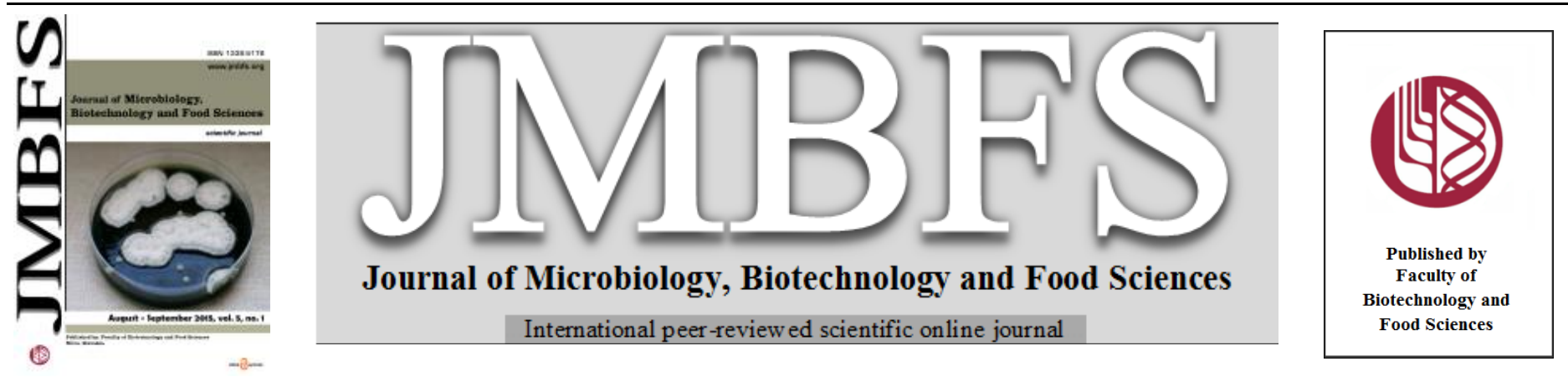

\title{
DEVELOPMENT OF A PRESERVATION TECHNIQUE FOR STRAWBERRY FRUIT (FRAGARIA $\times$ ANANASSA DUCH.) BY USING AQUEOUS CHLORINE DIOXIDE
}

\author{
Zhao Chen ${ }^{\text {I, }} 2$ \\ Address(es): \\ ${ }^{1}$ Deapartment of Biological Sciences, College of Agriculture, Forestry and Life Sciences, Clemson University, Clemson, SC 29634, US \\ ${ }^{2}$ Department of Microbiology, College of Life Sciences, Shandong Agricultural University, Taian, Shandong 271018, China
}

*Corresponding author: zchen5@clemson.edu

doi: 10.15414/jmbfs.2015.5.1.45-51

\section{ARTICLE INFO}

Received 16. 2. 2015

Revised 7. 3. 2015

Accepted 14. 5. 2015

Published 1. 8. 2015

Regular article

open $\bigodot_{\text {AcCESS }}$

\begin{abstract}
Effects of aqueous chlorine dioxide $\left(\mathrm{ClO}_{2}\right)$ treatment on preserving strawberry fruit (Fragaria $\times$ ananassa Duch.) were investigated. A stabilized $\mathrm{ClO}_{2}$ powder was dissolved in water to prepare the $\mathrm{ClO}_{2}$ solution. Strawberry fruit were then rinsed with $\mathrm{ClO}_{2}$ solutions at different concentrations $\left(20,40,60\right.$, and $80 \mathrm{mg} / \mathrm{L}$ ) for different times $(5,10$, and $15 \mathrm{~min})$ at $22 \pm 2^{\circ} \mathrm{C}$ and $70 \pm 5 \% \mathrm{RH}$. Following $\mathrm{ClO}_{2}$ treatments, strawberries were stored at $4^{\circ} \mathrm{C}$ for 9 days. $\mathrm{ClO}_{2}$ could markedly delay changes in firmness, slow down weight loss, and decay, and maintain sensory quality of strawberry fruit. $\mathrm{ClO}_{2}$ was also effective in retention of ascorbic acid, reducing sugar, and titratable acid. $\mathrm{ClO}_{2}$ concentration and treatment time were two significant factors $(\mathrm{P}<0.05)$. Strawberry fruit treated by $60 \mathrm{mg} / \mathrm{L} \mathrm{ClO} 2$ for $15 \mathrm{~min}$ were effectively preserved, the shelf-life of which were prolonged to 9 days compared to 5 days for the untreated control. $\mathrm{ClO}_{2}$ treatment was demonstrated to be a promising preservation technique for strawberry fruit.
\end{abstract}

\section{INTRODUCTION}

Strawberries are one of the most delicious and nutritious fruits. Strawberries are a non-climacteric fruit and must be harvested at full maturity to achieve the maximum quality according to flavor, nutritional value, sensory quality, and texture (Hernández-Munñz et al., 2006). Strawberry fruit are perishable after harvest due to their physiological characteristics and susceptibilities to be mechanically damaged and infected by phytopathogenic fungi, bacteria and viruses (Schestibratov and Dolgov, 2005). As a consequence, strawberries may lose their sensory properties and nutrients during storage. Currently, varieties of chemical additives have been employed to maintain the postharvest storage quality of strawberry fruit (Simpson et al., 2003; Simpson et al., 2004) However, these chemical treatments are usually high-cost, low-efficiency, and potentially harmful. Thus, physical methods such as heat, low temperature, modified atmosphere, and irradiation have been reported (Vicente $\boldsymbol{e t}$ al., 2002; Ayala-Zavala et al., 2004; Allende et al., 2007; Zheng et al., 2007; Martínez and Civello, 2008; Nielsen and Leufvén, 2008; Pombo et al., 2009). Most of the physical treatments have showed potential negative effects on nutritional and flavor components of strawberry fruit (Breitfellner et al., 2003; Cordenunsi et al., 2003; Sahari et al., 2004; Terefe et al., 2009). Therefore, exploring and utilizing new techniques to maintain the postharvest quality of strawberry fruit is necessary.

Chlorine dioxide $\left(\mathrm{ClO}_{2}\right)$ is a novel disinfectant and decontaminant. Because of its nontoxicity and not reacting with organic compounds to produce toxic chlorinated by-products (Gómez-López et al., 2007), aqueous $\mathrm{ClO}_{2}$ has already been approved by FDA since 1998 for sanitizing fruits and vegetable surfaces (FDA, 2014). Our previous research has demonstrated the beneficial effects of $\mathrm{ClO}_{2}$ treatments on the storage quality of fresh-cut asparagus lettuce, mulberry fruit, plum fruit, and chestnut kernel (Chen et al., 2010; Chen et al., 2011; Chen and Zhu, 2011a; Chen and Zhu, 2011b). However, research that mainly focuses on effects of $\mathrm{ClO}_{2}$ on postharvest storage quality and nutritional components of strawberry fruit is extremely scarce. The objective of this study was thus to develop a preservation technique for strawberry fruit by using aqueous chlorine dioxide. This will be the first study on the effects of aqueous $\mathrm{ClO}_{2}$ treatment on the storage quality and shelf-life of strawberry fruit.

\section{MATERIAL AND METHODS}

\section{Fruit material and preparation}

Strawberries (Fragaria $\times$ ananassa Duch. cv. Fengxiang) were harvested at full maturity (Total soluble solids: $7.5 \pm 0.2 \%$ ) at an orchard at Taian, China and immediately transported to the laboratory. Fruits were then sorted to select the ones with uniform size and color but without physical damage or decay.

\section{$\mathrm{ClO}_{2}$ preparation}

Stabilized $\mathrm{ClO}_{2}$ powder (Charmstar, Tianjin Charmstar Technology Development Co., Ltd, Tianjin, China) was dissolved in deionized water to prepare a stock solution with the concentration of about $100 \mathrm{mg} / \mathrm{L}$ according to the manufacturer's instructions. The concentration was measured by a standard method using iodimetry right before use (APHA, 1998). $\mathrm{ClO}_{2}$ solutions at specified concentrations could be prepared through dilution with deionized water.

\section{$\mathrm{ClO}_{2}$ treatment}

Strawberries were washed with tap water and drained well. Fruits were then immersed into $\mathrm{ClO}_{2}$ solutions at different concentrations $(20,40,60$, and 80 $\mathrm{mg} / \mathrm{L})$ for different times $(5,10$, and $15 \mathrm{~min}$ ) with a ratio of $1 \mathrm{~kg}: 5 \mathrm{~L}$ (Strawberry: $\mathrm{ClO}_{2}$ solution) at $22 \pm 2^{\circ} \mathrm{C}$. Solution residues on fruit surfaces were drained off after each treatment. Strawberries were then rinsed in potable tap water for $1 \mathrm{~min}$ according to the FDA information (FDA, 2014) and then airdried. Each treated group was packaged into an individual aseptic polyethylene bags (350 $\mathrm{mm} \times 250 \mathrm{~mm}, 0.02 \mathrm{~mm}$ thick; Baileyuan, Weifang Baileyuan Freshkeeping Package Co., Ltd, Weifang, China) and stored at $4^{\circ} \mathrm{C}$ for 9 days. Samples treated with potable tap water were regarded as the control to simulate the commercial industrial processing.

\section{Firmness}

Fruit firmness was measured every day during storage using a portable firmness tester (GY-1, Zhejiang Top Instrument Co., Ltd, Zhejiang, China). Each sample was tested twice on opposite sides of the equatorial zone. 


\section{Weight loss}

Strawberries were weighed right after treatments, and thereafter each day during the 9-day storage. Weight loss was expressed as percentage loss of the initial total weight.

\section{Decay rate}

Decay degree was evaluated on a modified 0-3 decay scale based on the surface area of macroscopic lesions, where $3=$ unacceptable, more than $30 \%$ of surface area showing decay; 2 = bad, $10-30 \%$ of surface area showing decay; $1=$ acceptable, less than $10 \%$ of surface area showing decay; $0=$ excellent, no visible decay detected (Zheng $\boldsymbol{e t}$ al., 2005). The overall decay rate of each treatment was calculated using the following formula:

Decay rate $(\%)=\frac{\sum(\text { Decay scale } \times \text { Number of fruit })}{\text { Highest decay scale } \times \text { Total number of fruit }} \times 100 \%$

\section{Contents of ascorbic acid, reducing sugar, and titratable acid}

The ascorbic acid, reducing sugar, and titratable acid contents of strawberry fruit were determined according to $\mathrm{Li}$ et al. (2009). The ascorbic acid was titrated using 2,6-dichloroindophenol titration method and its content was expressed as mg per $100 \mathrm{~g}$ of strawberry fruit. The content of reducing sugars was determined by the Fehling's method and was calculated as $\mathrm{g}$ of glucose per $100 \mathrm{~g}$ of strawberry fruit. The content of titratable acids was obtained by titration with 0.1 $\mathrm{mol} / \mathrm{L}$ sodium hydroxide to $\mathrm{pH} 8.2$ and expressed as $\mathrm{g}$ of malic acid per $100 \mathrm{~g}$ of strawberry fruit.

\section{Shelf-life}

After the study on the effects of $\mathrm{ClO}_{2}$ treatment on above storage quality parameters of strawberry fruit, the ideal $\mathrm{ClO}_{2}$ treatment condition was obtained to conduct the shelf-life study. Both the untreated control and $\mathrm{ClO}_{2}$ treated strawberries were stored at $4^{\circ} \mathrm{C}$ for $60 \mathrm{~d}$ for the shelf-life study. Samples washed with potable tap water were used as the control. Fruits were taken for microbial growth assay and sensory quality evaluation on day $0,3,5,7$, and 9 . Samples without being treated by potable tap water or $\mathrm{ClO}_{2}$ were used to determine the inherent background microflora. The end of the shelf-life was defined as when the population of a microbial group reached an unacceptable level or the sensory quality evaluation panelists rejected the fruit sample.

To perform microbial enumeration, $30 \mathrm{~g}$ of fruit sample was homogenized using a Stomacher 400 Circulator (Steward Ltd., London, UK) for $2 \mathrm{~min}$ in $270 \mathrm{ml}$ of sterile neutralizing phosphate buffer. Ten-fold dilution series were made in $0.1 \%$ peptone water for plating. The following media and conditions were used for microbial incubation: Plate Count Agar was incubated at $30^{\circ} \mathrm{C}$ for $3 \mathrm{~d}$ for total aerobic mesophilic bacteria and also at $22^{\circ} \mathrm{C}$ for $5 \mathrm{~d}$ for total aerobic psychrotrophic bacteria; de Man-Rogosa-Sharpe medium $(0.14 \%$ sorbic acid) was incubated at $30^{\circ} \mathrm{C}$ for $3 \mathrm{~d}$ for lactic acid bacteria; Rose Bengal Agar was incubated at $30^{\circ} \mathrm{C}$ for $3 \mathrm{~d}$ for yeasts and moulds. Colonies were counted and results expressed as $\log \mathrm{cfu} / \mathrm{g}$. The following microbiological specifications were used to determine the end of the shelf-life: $8 \mathrm{log} \mathrm{cfu} / \mathrm{g}$ for aerobic mesophilic bacteria and aerobic psychrotrophic bacteria, $7 \mathrm{log}$ cfu/g (plus sensory analysis) for lactic acid bacteria, and 5 log cfu/g for yeasts and moulds (Gómez-López et al., 2008).

Sensory quality was evaluated by a panel of ten trained judges. Overall visual quality (OVQ) was scored according to a 9-point hedonic scale (Chen et al., 2010): 9 = excellent, extremely fresh; $7=$ very good, marketable; $5=$ good, limit of marketability; 3 = fair, limit of usability; 1 = poor, unusable. The following sensory quality attributes were also evaluated according to Gómez-López et al. (2008): off-odor ( $1=$ none, $3=$ acceptable, $5=$ severe $)$; flavor $(1=$ fresh, $3=$ acceptable, $5=$ spoiled $)$; texture $(1=$ fresh, $3=$ acceptable, $5=$ spoiled $)$. The end of the shelf-life from the sensory quality point of view was reached when at least one of the mean scores was above the acceptability limit.

\section{Statistical analysis}

All experiments were performed in three trials. Data were subjected to the analysis of variance (ANOVA) to determine whether significant differences $(\mathrm{P}<0.05)$ between means of different treatments existed by using SigmaPlot 12.0 (Systat Software Inc., San Jose, CA, USA).

\section{RESULTS}

\section{Firmness}
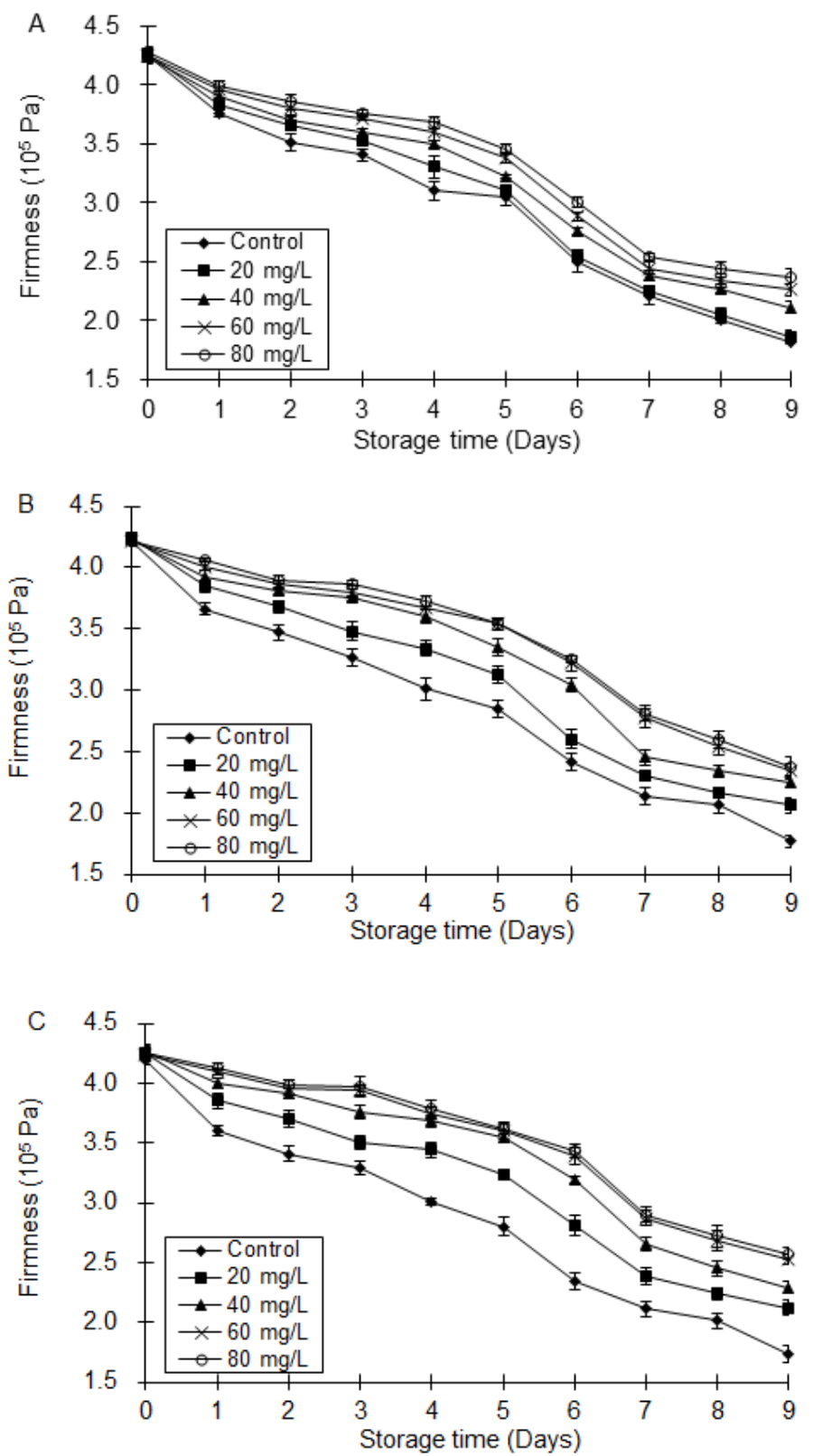

Figure 1 Effects of $\mathrm{ClO}_{2}$ treatment on firmness of strawberry fruit. The samples were treated by different concentrations of $\mathrm{ClO}_{2}(20,40,60$, and $80 \mathrm{mg} / \mathrm{L})$ for 5 $\min (\mathrm{A}), 10 \mathrm{~min}(\mathrm{~B})$, and $15 \mathrm{~min}(\mathrm{C})$. Vertical bars indicate standard deviation.

Firmness is one of the critical factors affecting the storage quality of strawberry fruit. The effects of $\mathrm{ClO}_{2}$ treatment on firmness of strawberry is shown in Fig. 1 Firmness values of the untreated control and the $\mathrm{ClO}_{2}$ treated samples decreased with prolonged storage time. Firmness of the control and the samples treated by $20 \mathrm{mg} / \mathrm{L} \mathrm{ClO}$ for $5 \mathrm{~min}$ was similar in the last 5 days $(\mathrm{P}>0.05)$ and dropped to less than $2.00 \times 10^{5} \mathrm{~Pa}$ on day 9 . Treatments with 60 and $80 \mathrm{mg} / \mathrm{L} \mathrm{ClO}_{2}$ were more effective and significantly different from other $\mathrm{ClO}_{2}$ treatments $(\mathrm{P}<0.05)$. When treatment time was prolonged to $15 \mathrm{~min}$, firmness values of samples treated by 60 and $80 \mathrm{mg} / \mathrm{L} \mathrm{ClO}_{2}$ were similar during 9-day storage $(\mathrm{P}>0.05)$. For 60 and 80 $\mathrm{mg} / \mathrm{L} \mathrm{ClO} 2$ treatments, firmness of the 15 min treated samples declined more slowly as compared to 5 and 10 min treated samples $(\mathrm{P}<0.05)$. 


\section{Weight loss}
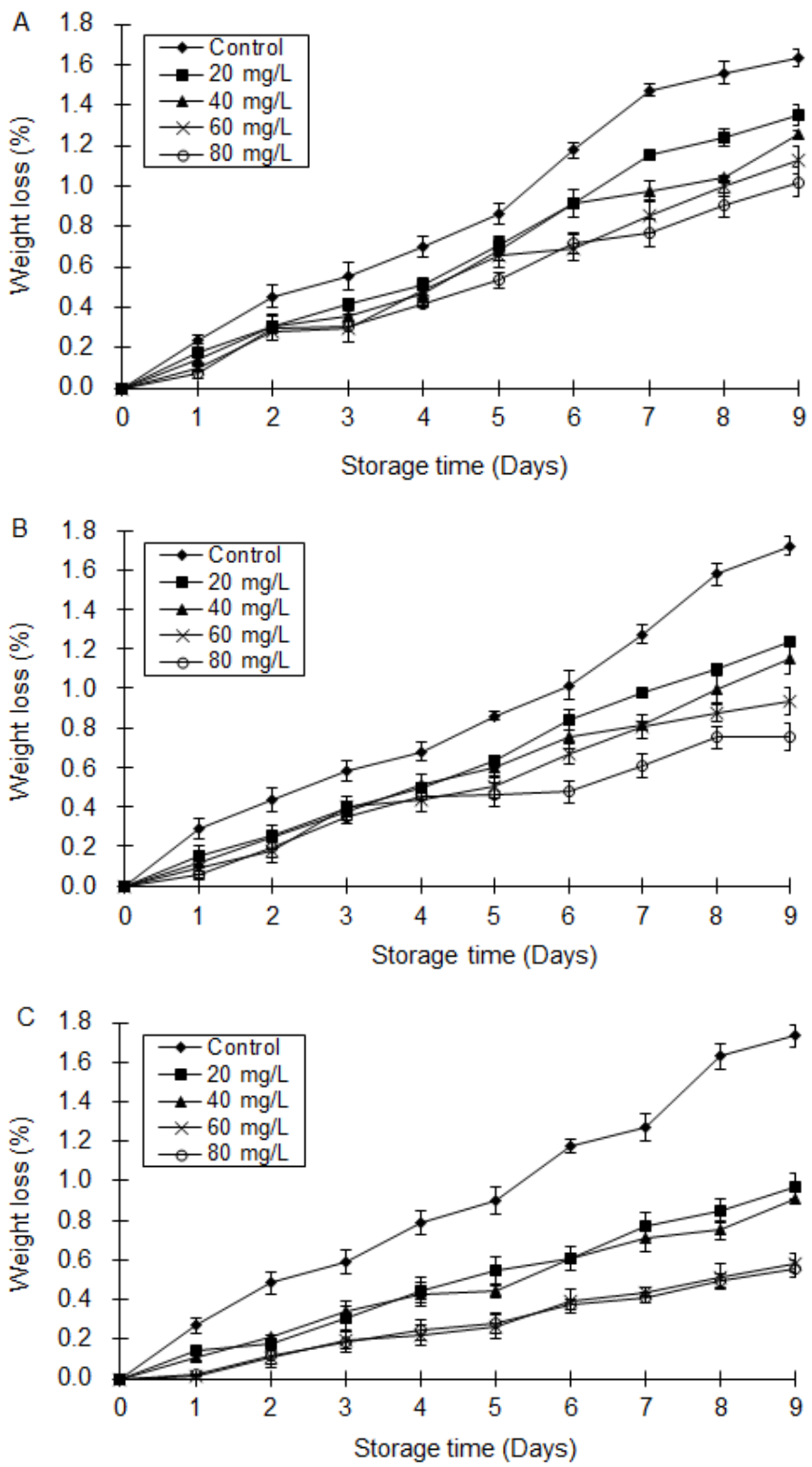

Figure 2 Effects of $\mathrm{ClO}_{2}$ treatment on weight loss of strawberry fruit. The samples were treated by different concentrations of $\mathrm{ClO}_{2}(20,40,60$, and 80 $\mathrm{mg} / \mathrm{L}$ ) for $5 \mathrm{~min}(\mathrm{~A}), 10 \mathrm{~min}(\mathrm{~B})$, and $15 \mathrm{~min}(\mathrm{C})$. Vertical bars indicate standard deviation.

Weight loss was determined to evaluate the effects of $\mathrm{ClO}_{2}$ treatment on maintaining the weight of strawberry fruit. All samples displayed weight loss with respect to the initial weight (Fig. 2). At the end of storage, the untreated control lost more than $1.60 \%$ of the initial weight. The $\mathrm{ClO}_{2}$ treated samples presented a significantly lower weight loss than the control during storage $(\mathrm{P}<0.05)$. Compared to 5 and $10 \mathrm{~min}$ treatments, the samples treated by 60 and 80 $\mathrm{mg} / \mathrm{L} \mathrm{ClO}_{2}$ for $15 \mathrm{~min}$ generated significantly lower weight losses $(\mathrm{P}<0.05)$ When treatment time was extended to $15 \mathrm{~min}$, weight losses of samples treated by 60 and $80 \mathrm{mg} / \mathrm{L} \mathrm{ClO}{ }_{2}$ were significantly lower when compared with 20 and 40 $\mathrm{mg} / \mathrm{L} \mathrm{ClO}$ treatments $(\mathrm{P}<0.05)$. The differences between treatments with 60 and $80 \mathrm{mg} / \mathrm{L} \mathrm{ClO}$ for $15 \mathrm{~min}$ were not significant $(\mathrm{P}>0.05)$.
Decay rate
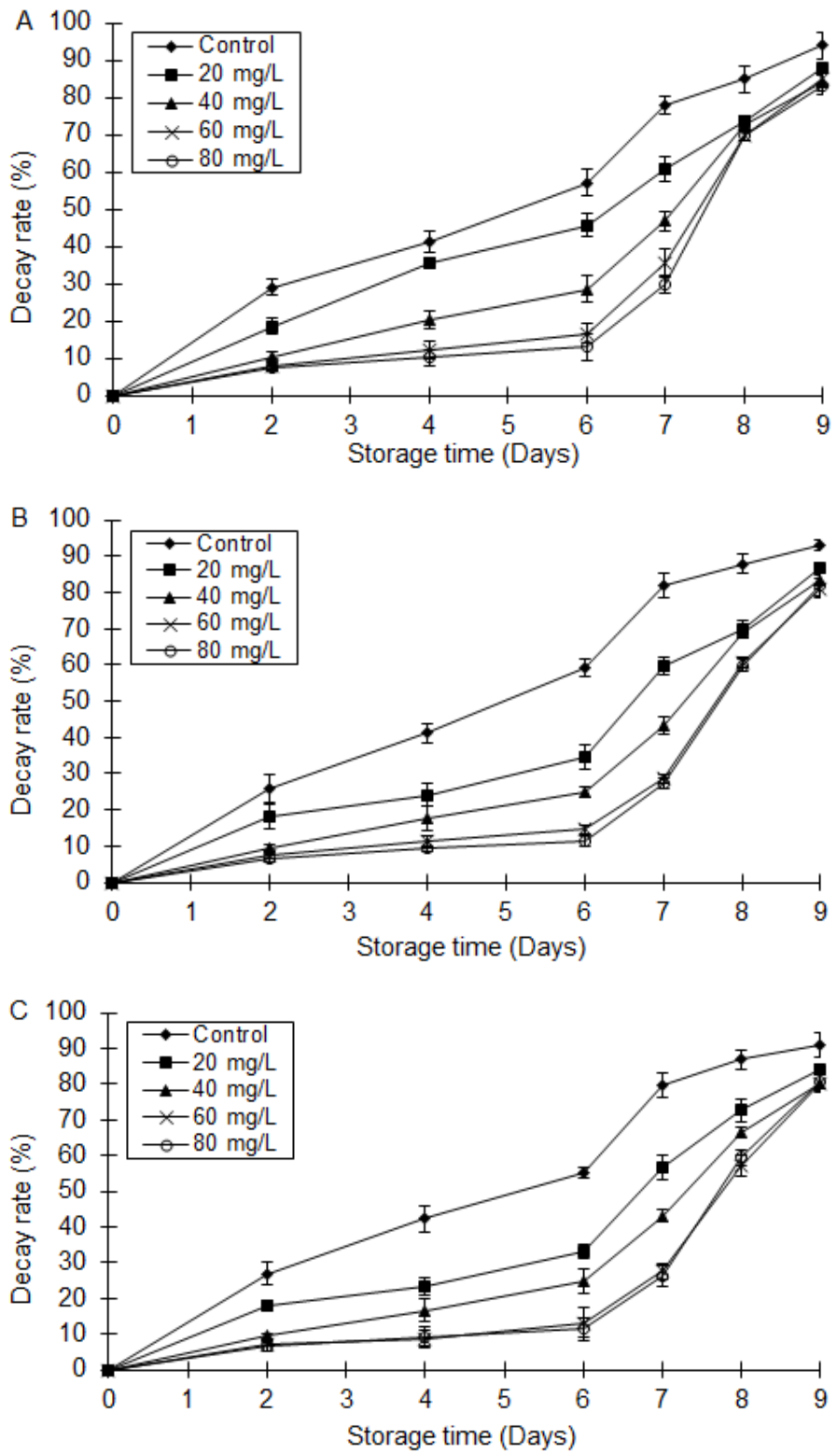

Figure 3 Effects of $\mathrm{ClO}_{2}$ treatment on decay rate of strawberry fruit. The samples were treated by different concentrations of $\mathrm{ClO}_{2}(20,40,60$, and $80 \mathrm{mg} / \mathrm{L})$ for 5 $\min (\mathrm{A}), 10 \mathrm{~min}(\mathrm{~B})$, and $15 \mathrm{~min}(\mathrm{C})$. Vertical bars indicate standard deviation.

As shown in Fig. 3, decay rates for all the samples increased with storage time Compared to the untreated control, decay rates in $\mathrm{ClO}_{2}$ treated samples were significantly lower $(\mathrm{P}<0.05)$. Decay rate became lower as $\mathrm{ClO}_{2}$ concentration was increased and treatment time was prolonged. Within 8 days of storage, compared to 20 and $40 \mathrm{mg} / \mathrm{L} \mathrm{ClO}$ treatments, samples treated by 60 and $80 \mathrm{mg} / \mathrm{L} \mathrm{ClO}$ showed much lower decay rates $(\mathrm{P}<0.05)$. At the end of storage, no significant differences were observed among 40,60, and $80 \mathrm{mg} / \mathrm{L} \mathrm{ClO}_{2}(\mathrm{P}>0.05)$. For 60 and $80 \mathrm{mg} / \mathrm{L} \mathrm{ClO}{ }_{2}$ treatments, decay rates for samples treated for 10 and 15 min were similar $(\mathrm{P}>0.05)$. 
Contents of ascorbic acid, reducing sugar and titratable acid
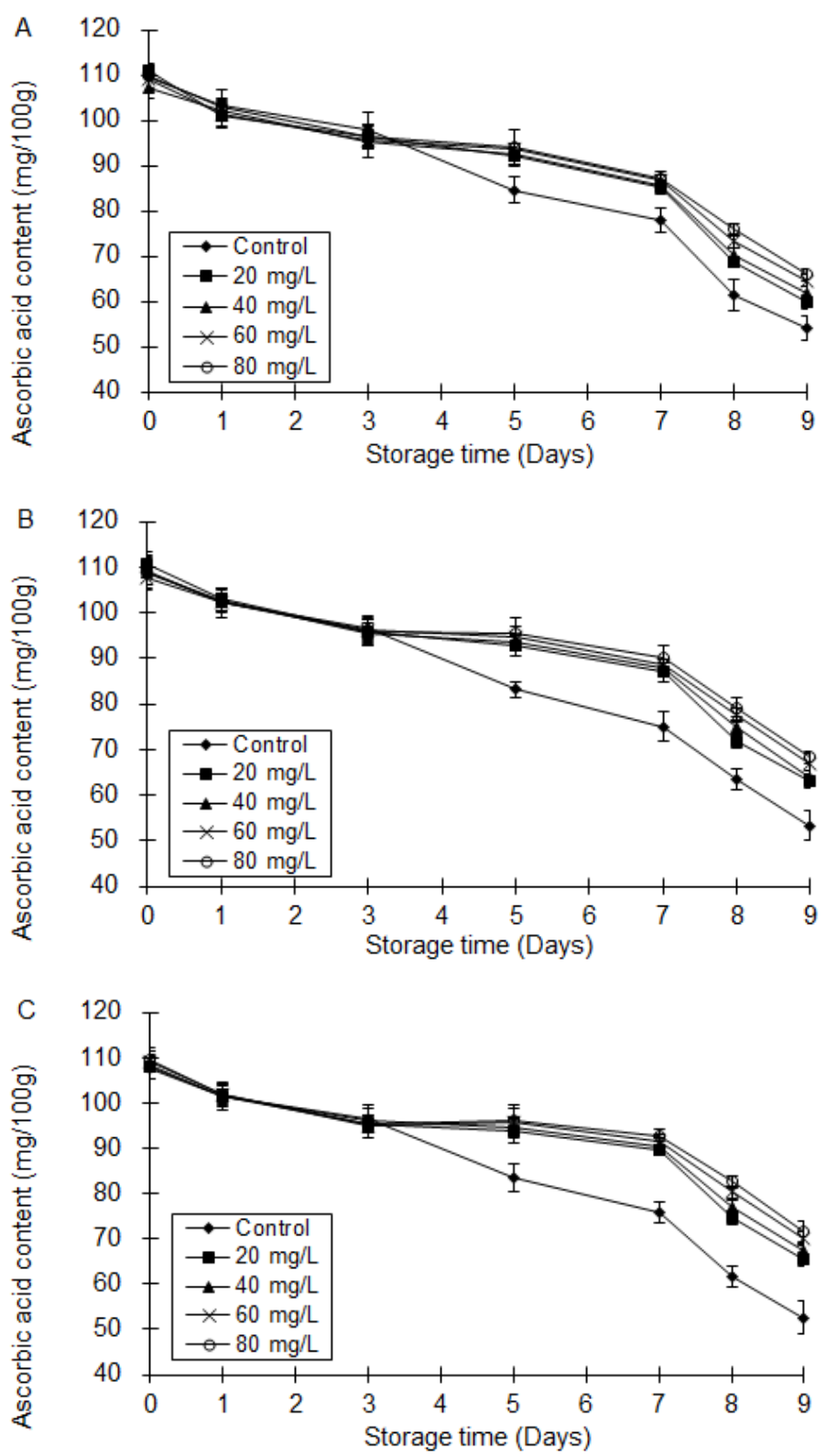

Figure 4 Effects of $\mathrm{ClO}_{2}$ treatment on ascorbic acid content of strawberry fruit The samples were treated by different concentrations of $\mathrm{ClO}_{2}(20,40,60$, and 80 $\mathrm{mg} / \mathrm{L}$ ) for $5 \mathrm{~min}(\mathrm{~A}), 10 \mathrm{~min}(\mathrm{~B})$, and $15 \mathrm{~min}(\mathrm{C})$. Vertical bars indicate standard deviation.

In view of strawberry as a source of ascorbic acid, the ascorbic acid content of strawberry fruit during storage was determined. Initial contents of ascorbic acid in the control and $\mathrm{ClO}_{2}$ treated samples were similar $(\mathrm{P}>0.05)$. As shown in Fig. 4 , a remarkable decrease was detected in all samples. Ascorbic acid contents of the $\mathrm{ClO}_{2}$ treated samples were lower than those of the control in the first 3 days of storage; however, the differences between them were not significant $(\mathrm{P}>0.05)$ From day 5 , the contents of $\mathrm{ClO}_{2}$ treated samples became higher comparing with the control $(\mathrm{P}<0.05)$. The 60 and $80 \mathrm{mg} / \mathrm{L} \mathrm{ClO}{ }_{2}$ treatments were more effective than the 20 and $40 \mathrm{mg} / \mathrm{L} \mathrm{ClO}_{2}$ treatments in retaining ascorbic acid. For 60 and $80 \mathrm{mg} / \mathrm{L} \mathrm{ClO}$ treatments, compared to 5 and 10 min $\mathrm{ClO}_{2}$ treated samples, the contents of 15 min $\mathrm{ClO}_{2}$ treated samples were significantly higher $(\mathrm{P}<0.05)$ Samples treated by 60 and $80 \mathrm{mg} / \mathrm{L} \mathrm{ClO}$ for 15 min exhibited more than 70 $\mathrm{mg} / 100 \mathrm{~g}$ ascorbic acid contents at the end of storage $(\mathrm{P}>0.05)$.
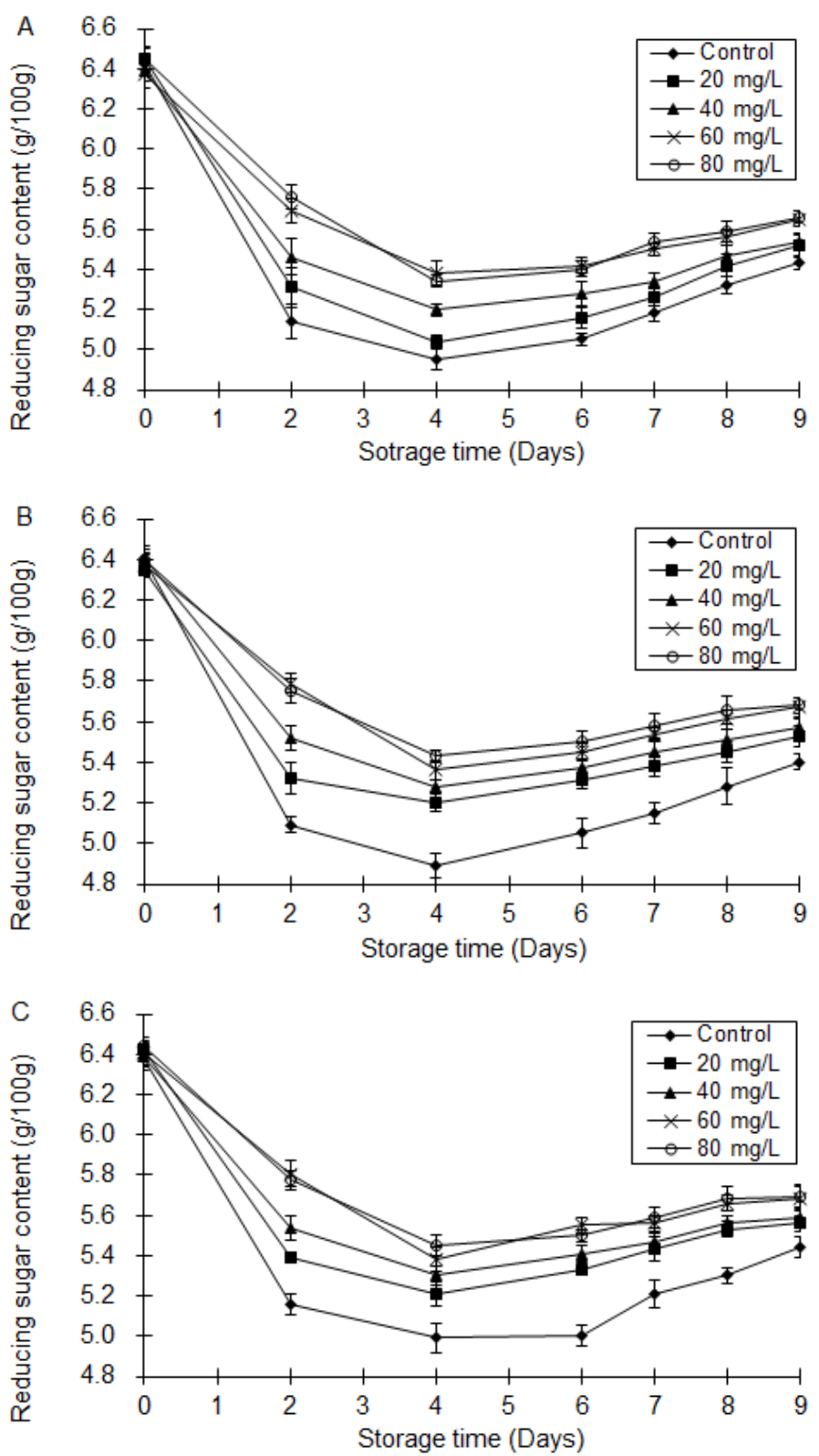

Figure 5 Effects of $\mathrm{ClO}_{2}$ treatment on reducing sugar content of strawberry fruit. The samples were treated by different concentrations of $\mathrm{ClO}_{2}(20,40,60$, and 80 $\mathrm{mg} / \mathrm{L}$ ) for $5 \mathrm{~min}(\mathrm{~A}), 10 \mathrm{~min}(\mathrm{~B})$, and $15 \mathrm{~min}(\mathrm{C})$. Vertical bars indicate standard deviation

The effects of $\mathrm{ClO}_{2}$ treatment on reducing sugar content in strawberry fruit are shown in Fig. 5. There were no significant differences in initial reducing sugar contents among all samples $(\mathrm{P}>0.05)$. Reducing sugar contents of the control and $\mathrm{ClO}_{2}$ treated samples decreased in the first 4 days, then increased gradually throughout the remaining time. Though contents of all samples showed the same changing trends over storage period, contents of the $\mathrm{ClO}_{2}$ treated samples were higher than those of the control $(\mathrm{P}<0.05)$. The most effective treatment for retention of reducing sugar was achieved at higher $\mathrm{ClO}_{2}$ concentrations and longer treatment times. Compared to 20 and $40 \mathrm{mg} / \mathrm{L} \mathrm{ClO}_{2}$ treatments, reducing sugar contents of 60 and $80 \mathrm{mg} / \mathrm{L} \mathrm{ClO}$ treated samples were higher during storage $(\mathrm{P}<0.05)$. The $60 \mathrm{mg} / \mathrm{L} \mathrm{ClO}{ }_{2}$ treatments were similar with the $80 \mathrm{mg} / \mathrm{L}$ $\mathrm{ClO}_{2}$ treatments $(\mathrm{P}>0.05)$. Considering treatment time, reducing sugar contents of samples treated by $\mathrm{ClO}_{2}$ for 10 and 15 min were similar $(\mathrm{P}>0.05)$ 

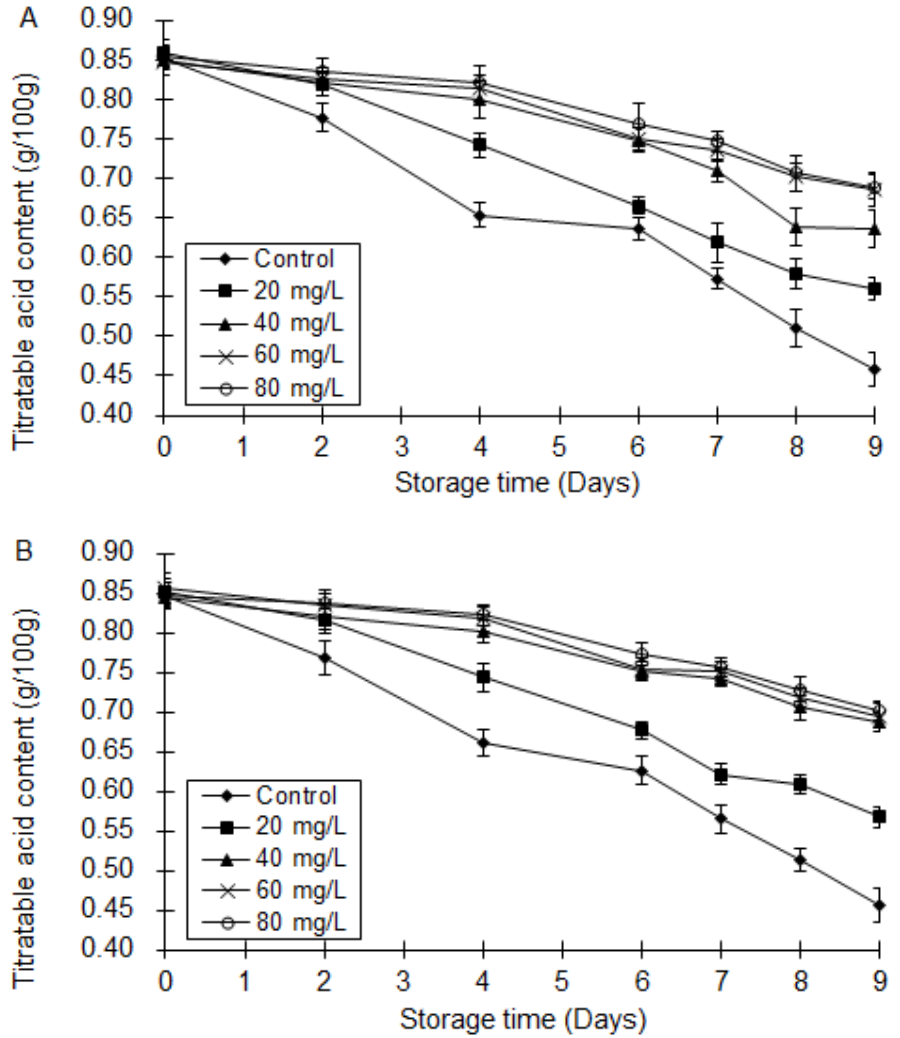

\begin{tabular}{|c|c|c|c|c|c|c|}
\hline \multirow{2}{*}{ Microbial group } & \multirow{2}{*}{ Treatment } & \multicolumn{5}{|c|}{ Storage time (days) } \\
\hline & & 0 & 3 & 5 & 7 & 9 \\
\hline \multirow{2}{*}{ Aerobic mesophilic bacteria } & Control & $4.3 \pm 0.2^{*} \mathrm{a}^{* *}$ & $5.9 \pm 0.6 \mathrm{a}$ & $6.9 \pm 0.2 \mathrm{a}$ & $8.3 \pm 0.4 \mathrm{a}$ & \\
\hline & $\mathrm{ClO}_{2}$ treatment & $2.1 \pm 0.4 \mathrm{~b}$ & $3.3 \pm 0.3 \mathrm{~b}$ & $4.5 \pm 0.4 \mathrm{~b}$ & $\overline{5.7 \pm 0.5 b}$ & $6.6 \pm 0.3$ \\
\hline \multirow{2}{*}{ Aerobic psychrotrophic bacteria } & Control & $4.1 \pm 0.2 \mathrm{a}$ & $5.6 \pm 0.3 \mathrm{a}$ & $6.8 \pm 0.4 \mathrm{a}$ & $8.1 \pm 0.4 \mathrm{a}$ & - \\
\hline & $\mathrm{ClO}_{2}$ treatment & $2.0 \pm 0.3 b$ & $3.1 \pm 0.2 \mathrm{~b}$ & $4.2 \pm 0.3 \mathrm{~b}$ & $\overline{5.5 \pm 0.3 \mathrm{~b}}$ & $6.4 \pm 0.4$ \\
\hline \multirow{2}{*}{ Lactic acid bacteria } & Control & $1.5 \pm 0.5 \mathrm{a}$ & $2.3 \pm 0.4 \mathrm{a}$ & $3.3 \pm 0.2 \mathrm{a}$ & $4.5 \pm 0.3 \mathrm{a}$ & $5.9 \pm 0.5 \mathrm{a}$ \\
\hline & $\mathrm{ClO}_{2}$ treatment & $0.7 \pm 0.1 \mathrm{~b}$ & $1.4 \pm 0.3 \mathrm{~b}$ & $2.0 \pm 0.3 b$ & $2.9 \pm 0.4 \mathrm{~b}$ & $3.3 \pm 0.2 b$ \\
\hline \multirow{2}{*}{ Yeasts and moulds } & Control & $3.0 \pm 0.3 \mathrm{a}$ & $3.9 \pm 0.3 \mathrm{a}$ & $4.7 \pm 0.3 \mathrm{a}$ & $5.6 \pm 0.4 \mathrm{a}$ & - \\
\hline & $\mathrm{ClO}_{2}$ treatment & $1.6 \pm 0.4 \mathrm{~b}$ & $2.2 \pm 0.2 \mathrm{~b}$ & $2.9 \pm 0.2 \mathrm{~b}$ & $3.6 \pm 0.3 b$ & $4.5 \pm 0.3$ \\
\hline
\end{tabular}

Legend: "Data are expressed as means \pm SD of triplicate assays. Numbers with underlines are counts above the acceptability limit.

${ }^{* *}$ Within the same microbial group, means with different letters for the same storage time are significantly different $(\mathrm{P}<0.05)$ according to the LSD test.

${ }^{* * *}-$, not detected.

Changes in the microflora of strawberry fruit during storage were evaluated with changes in microbial counts for aerobic mesophilic bacteria, aerobic psychrotrophic bacteria, lactic acid bacteria, and yeast and mold immediately after $\mathrm{ClO}_{2}$ treatments and during storage (Table 1). High loads of aerobic mesophilic bacteria $(4.4 \pm 0.4 \mathrm{log} \mathrm{cfu} / \mathrm{g})$ and aerobic psychrotrophic bacteria $(4.2 \pm 0.2 \log \mathrm{cfu} / \mathrm{g})$ were observed in raw fruit. Lactic acid bacteria $(1.7 \pm 0.3 \mathrm{log}$ $\mathrm{cfu} / \mathrm{g})$, yeasts and moulds $(3.2 \pm 0.2 \mathrm{log} \mathrm{cfu} / \mathrm{g})$ were present in relatively lower counts. Microbial populations decreased in the control and $\mathrm{ClO}_{2}$ treated samples after washing, whereas the $\mathrm{ClO}_{2}$ treatments significantly decreased the microflora in strawberry fruit compared to the control $(\mathrm{P}<0.05)$. Microbial populations showed a gradual increase during storage in all samples; However, the populations in the $\mathrm{ClO}_{2}$ treated samples were maintained at significantly lower levels than those in the control $(\mathrm{P}<0.05)$. The counts of aerobic mesophilic

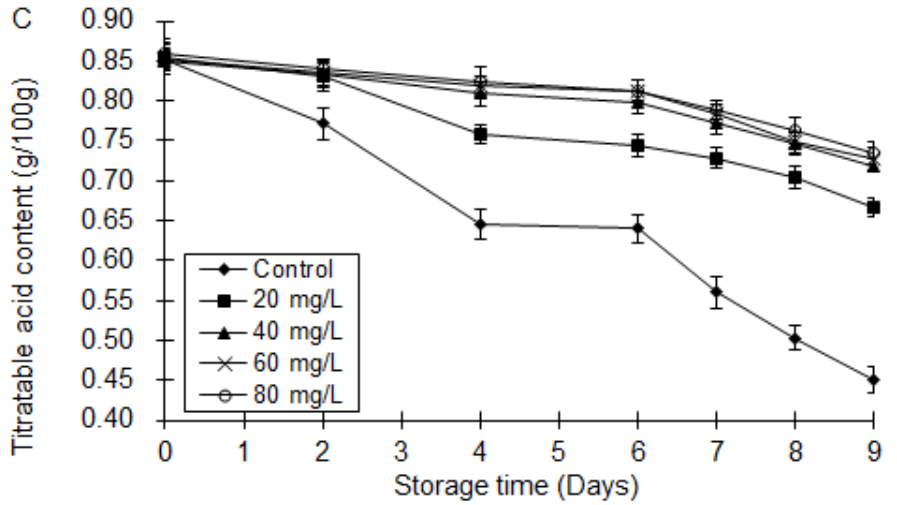

Figure 6 Effects of $\mathrm{ClO}_{2}$ treatment on titratable acid content of strawberry fruit The samples were treated by different concentrations of $\mathrm{ClO}_{2}(20,40,60$, and 80 $\mathrm{mg} / \mathrm{L}$ ) for $5 \mathrm{~min}(\mathrm{~A}), 10 \mathrm{~min}(\mathrm{~B})$, and $15 \mathrm{~min}(\mathrm{C})$. Vertical bars indicate standard deviation.

The effects of $\mathrm{ClO}_{2}$ treatment on titratable acid content are presented in Fig. 6 Initial titratable acid contents in all samples were similar $(\mathrm{P}>0.05)$. Titratable acid contents of the control and $\mathrm{ClO}_{2}$ treated samples decreased during storage. The titratable acid content of the control dropped drastically to about $0.45 \mathrm{~g} / 100 \mathrm{~g}$ on the last storage day. However, the contents of the $\mathrm{ClO}_{2}$ treated samples remained higher than those of the control during storage $(\mathrm{P}<0.05)$. All the $\mathrm{ClO}_{2}$ treatments were similar in the first 2 days $(\mathrm{P}>0.05)$. From day 4 , compared to the $20 \mathrm{mg} / \mathrm{L}$ $\mathrm{ClO}_{2}$ treatment, titratable acid contents of samples treated by 40,60 and $80 \mathrm{mg} / \mathrm{L}$

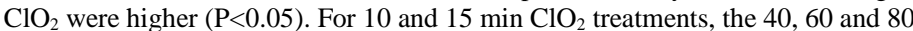
The titratable acid contents of the 5, 10 and $15 \mathrm{~min} \mathrm{ClO}_{2}$ treated samples were not significantly different in the first 4 days $(\mathrm{P}>0.05)$. From day 6 , the contents of the 15 min $\mathrm{ClO}_{2}$ treated samples became higher comparing with 5 and 10 min $\mathrm{ClO}_{2}$ treatments $(\mathrm{P}<0.05)$.

The differences between the effects of 60 and $80 \mathrm{mg} / \mathrm{L} \mathrm{ClO}_{2}$ treatments on above storage quality parameters were not significant $(\mathrm{P}>0.05)$. Therefore, the treatment with $60 \mathrm{mg} / \mathrm{L} \mathrm{ClO}_{2}$ for $15 \mathrm{~min}$ was selected as the ideal $\mathrm{ClO}_{2}$ treatment condition to investigate the effect of $\mathrm{ClO}_{2}$ treatment on shelf-life from microbiological and sensory quality perspectives.

Shelf-life $\mathrm{mg} / \mathrm{L} \mathrm{ClO} \mathrm{Cl}_{2}$ treatments were similar throughout entire storage period $(\mathrm{P}>0.05)$. bacteria and aerobic psychrotrophic bacteria reached more than $8 \mathrm{log} \mathrm{cfu} / \mathrm{g}$ in control on day 7 while maintained acceptable in $\mathrm{ClO}_{2}$ treated samples throughout the 9-day storage. The count of yeasts and molds in the control reached more than $5 \log \mathrm{cfu} / \mathrm{g}$ in control on day 7, whereas the count of $\mathrm{ClO}_{2}$ treated samples remained acceptable throughout the 9-day storage. Populations of lactic acid bacteria in the control and $\mathrm{ClO}_{2}$ treated samples also increased during storage; however, the counts did not reach unacceptable levels. Therefore, lactic acid bacteria could not be considered as a determinant in the shelf-life study. When analyzed together with the populations of aerobic mesophilic bacteria, aerobic psychrotrophic bacteria, and yeasts and molds, it can be concluded that, from the microbiological point of view, 4 extra days in shelf-life was achieved by the 60 $\mathrm{mg} / \mathrm{L} \mathrm{ClO}{ }_{2}$ treatment for $15 \mathrm{~min}$. 
Table 2 Effect of $60 \mathrm{mg} / \mathrm{L} \mathrm{ClO}$ treatment for $15 \mathrm{~min}$ on sensory quality of strawberry fruit

\begin{tabular}{|c|c|c|c|c|c|c|}
\hline \multirow{2}{*}{ Sensory quality attribute } & \multirow{2}{*}{ Treatment } & \multicolumn{5}{|c|}{ Storage time (days) } \\
\hline & & 0 & 3 & 5 & 7 & 9 \\
\hline \multirow{2}{*}{ OVQ } & Control & $9.0 \pm 0.0{ }^{*} \mathrm{a}^{* *}$ & $7.3 \pm 0.3 b$ & $6.1 \pm 0.4 \mathrm{~b}$ & $4.6 \pm 0.3 \mathrm{~b}$ & $-{ }^{*}$ \\
\hline & $\mathrm{ClO}_{2}$ treatment & $9.0 \pm 0.0 \mathrm{a}$ & $8.5 \pm 0.4 \mathrm{a}$ & $7.9 \pm 0.3 \mathrm{a}$ & $\overline{7.3 \pm 0.3 \mathrm{a}}$ & $6.8 \pm 0.5$ \\
\hline \multirow{2}{*}{ Off-odor } & Control & $1.0 \pm 0.0 \mathrm{a}$ & $2.1 \pm 0.4 \mathrm{a}$ & $2.6 \pm 0.4 \mathrm{a}$ & $\underline{3.7 \pm 0.2 \mathrm{a}}$ & - \\
\hline & $\mathrm{ClO}_{2}$ treatment & $1.0 \pm 0.0 \mathrm{a}$ & $1.5 \pm 0.2 b$ & $1.7 \pm 0.3 b$ & $\overline{2.0 \pm 0.2 \mathrm{~b}}$ & $2.5 \pm 0.3$ \\
\hline \multirow{2}{*}{ Flavor } & Control & $1.0 \pm 0.0 \mathrm{a}$ & $2.2 \pm 0.2 \mathrm{a}$ & $2.8 \pm 0.3 \mathrm{a}$ & $3.4 \pm 0.3 \mathrm{a}$ & - \\
\hline & $\mathrm{ClO}_{2}$ treatment & $1.0 \pm 0.0 \mathrm{a}$ & $1.2 \pm 0.3 b$ & $1.5 \pm 0.2 b$ & $1.8 \pm 0.2 \mathrm{~b}$ & $2.4 \pm 0.4$ \\
\hline \multirow{2}{*}{ Texture } & Control & $1.0 \pm 0.0 \mathrm{a}$ & $2.5 \pm 0.4 \mathrm{a}$ & $2.6 \pm 0.3 \mathrm{a}$ & $\underline{3.3 \pm 0.4 \mathrm{a}}$ & - \\
\hline & $\mathrm{ClO}_{2}$ treatment & $1.0 \pm 0.0 \mathrm{a}$ & $1.2 \pm 0.1 \mathrm{~b}$ & $1.4 \pm 0.2 \mathrm{~b}$ & $\overline{1.6 \pm 0.3 \mathrm{~b}}$ & $2.2 \pm 0.2$ \\
\hline
\end{tabular}

Legend: "Data are expressed as means \pm SD of triplicate assays. Numbers with underlines are scores above the acceptability limit.

${ }^{* *}$ Within the same sensory quality attribute, means with different letters for the same storage time are significantly different $(\mathrm{P}<0.05)$ according to the LSD test.

**, not detected.

As shown in Table 2, immediately after washing, there were no significant differences in the same sensory quality attribute between the control and $\mathrm{ClO}_{2}$ treated samples $(\mathrm{P}>0.05)$. Sensory quality declined in all samples as storage time prolonged. Overall visual quality, off-odor, flavor, and texture of the control were all above the acceptability limit after 7 days; however, the samples treated by 60 $\mathrm{mg} / \mathrm{L} \mathrm{ClO}_{2}$ for $15 \mathrm{~min}$ maintained higher sensory quality as compared to the control during storage $(\mathrm{P}<0.05)$. And sensory quality of the $\mathrm{ClO}_{2}$ treated samples remained acceptable throughout the entire storage. From the sensory quality point of view, a shelf-life prolongation of 4 days was achieved by the $60 \mathrm{mg} / \mathrm{L} \mathrm{ClO}_{2}$ treatment for $15 \mathrm{~min}$, which was consistent with the microbial growth assay. Therefore, the shelf-life of strawberry fruit treated by $60 \mathrm{mg} / \mathrm{L} \mathrm{ClO}_{2}$ for $15 \mathrm{~min}$ was prolonged to 9 days compared to 5 days for the untreated control.

\section{DISCUSSION}

Aqueous $\mathrm{ClO}_{2}$ has been proved to be effective in preserving postharvest fruits and vegetables. Du et al. (2009) found that higher aqueous $\mathrm{ClO}_{2}$ concentration and longer treatment time provided better inhibitory effects on enzymatic browning of fresh-cut lotus root. In our previous studies, $\mathrm{ClO}_{2}$ concentration and treatment time have also been found to be two critical factors affecting the effects of $\mathrm{ClO}_{2}$ treatment on fresh produce (Chen et al., 2010; Chen et al., 2011; Chen and Zhu, 2011a; Chen and Zhu, 2011b). In the present study, with increased $\mathrm{ClO}_{2}$ concentration and treatment time, postharvest storage quality of strawberry fruit was more effectively maintained, which are consistent with published data. $\mathrm{ClO}_{2}$ as a powerful oxidant may lead to the oxidation of ascorbic acid during treatment (Du et al., 2007). $\mathrm{ClO}_{2}$ may also oxidize some components including pigments on produce surfaces and suppress color formation (Fu et al., 2007). Du et al. (2007) reported that though the loss of ascorbic acid in $\mathrm{ClO} 2$ treated green bell peppers was drastic in the first $10 \mathrm{~d}$, it was retarded after $20 \mathrm{~d}$, resulting in higher contents of ascorbic acid after $40 \mathrm{~d}$. Similarly, our previous study also showed that flavonoid and ascorbic acid contents of the $\mathrm{ClO}_{2}$ treated mulberry fruits were lower than those of the control in the early storage days; however, as storage time extended, $\mathrm{ClO}_{2}$ treatments showed the ability to slow down the loss of nutritional components (Chen et al., 2011). In this study, ascorbic acid contents of $\mathrm{ClO}_{2}$ treated strawberry fruits were slightly lower than those of the control during the early days but tended to be higher as storage time prolonged. Therefore, $\mathrm{ClO}_{2}$ showed the ability to retard the loss of ascorbic acid. Further research is warranted to investigate the mechanism of $\mathrm{ClO}_{2}$ treatment on nutritional components of fresh fruits and vegetables.

Our previous studies have showed that there was no detectable $\mathrm{ClO}_{2}$ residue in $\mathrm{ClO}_{2}$ treated plum or mulberry fruits (Chen et al., 2011; Chen and Zhu, 2011a) These results may attribute to the potable tap water rinse after $\mathrm{ClO}_{2}$ treatment according to the USFDA information (2014), which is designed to remove any $\mathrm{ClO}_{2}$ residue on fruit and vegetable surfaces. In consideration of the significance of food safety to consumers, it is strongly recommended that $\mathrm{ClO}_{2}$ treatments of fruits and vegetables should be followed by a potable water rinse.

\section{CONCLUSION}

$\mathrm{ClO}_{2}$ treatment effectively maintained postharvest storage quality and extended shelf-life of strawberry fruit. $\mathrm{ClO}_{2}$ concentration and treatment time were two critical factors affecting $\mathrm{ClO}_{2}$ treatment. The treatment with $60 \mathrm{mg} / \mathrm{L}$ for $15 \mathrm{~min}$ was the ideal condition for preserving strawberry fruit. $\mathrm{ClO}_{2}$ was therefore demonstrated to be a promising approach to preserve postharvest strawberry fruit.

\section{REFERENCES}

ALLENDE, A., MARÍN, A., BUENDÍA, B., TOMÁS-BARBERÁN, F., GIL, M.I. 2007. Impact of combined postharvest treatments (UV-C light, gaseous $\mathrm{O}_{3}$, superatmospheric $\mathrm{O}_{2}$ and high $\mathrm{CO}_{2}$ ) on health promoting compounds and shelflife of strawberries. Postharvest Biology and Technology, 46, 201-211. http://dx.doi.org/10.1016/j.postharvbio.2007.05.007

APHA. 1998. Standard methods for the examination of water and waste water. American Public Health Association, Washington DC.
AYALA-ZAVALA, J.F., WANG, S.Y., WANG, C.Y., GONZÁLEZ-AGUILAR, G.A. 2004. Effect of storage temperatures on antioxidant capacity and aroma compounds in strawberry fruit. LWT - Food Science and Technology, 37, 687695. http://dx.doi.org/10.1016/j.lwt.2004.03.002

BREITFELLNER, F., SOLAR, S., SONTAG, G. 2003. Radiation induced chemical changes of phenolic compounds in strawberries. Radiation Physics and Chemistry, 67, 497-499. http://dx.doi.org/10.1016/S0969-806X(03)00092-6

CHEN, Z., ZHU, C., ZHANG, Y., NIU, D., DU, J. 2010. Effects of aqueous chlorine dioxide treatment on enzymatic browning and shelf-life of fresh-cut asparagus lettuce (Lactuca sativa L.). Postharvest Biology and Technology, 58, 232-238. http://dx.doi.org/10.1016/j.postharvbio.2010.06.004

CHEN, Z., ZHU, C., HAN, Z. 2011. Effects of aqueous chlorine dioxide treatment on nutritional components and shelf-life of mulberry fruit (Morus alba L.). Journal of Bioscience and Bioengineering, 111, 675-681. http://dx.doi.org/10.1016/j.jbiosc.2011.01.010

CHEN, Z., ZHU, C. 2011a. Combined effects of aqueous chlorine dioxide and ultrasonic treatments on postharvest storage quality of plum fruit (Prunus salicina L.). Postharvest Biology and Technology, 61, 117-123. http://dx.doi.org/10.1016/j.postharvbio.2011.03.006

CHEN, Z., ZHU, C. 2011b. Modelling inactivation by aqueous chlorine dioxide of Dothiorella gregaria Sacc. and Fusarium tricinctum (Corda) Sacc. spores inoculated on fresh chestnut kernel. Letters in Applied Microbiology, 52, 676684. http://dx.doi.org/10.1111/j.1472-765X.2011.03061.x

CORDENUNSI, B.R., NASCIMENTO, J.R.O., LAJOLO, F.M. 2003. Physicochemical changes related to quality of five strawberry fruit cultivars during coolstorage. Food Chemistry, 83, 167-173. http://dx.doi.org/10.1016/S0308 $\underline{8146(03) 00059-1}$

DU, J., FU, M., LI M., XIA, W. 2007. Effects of chlorine dioxide gas on postharvest physiology and storage quality of green bell pepper (Capsicum frutescens L. var. Longrum). Agricultural Sciences in China, 6, 214-219. http://dx.doi.org/10.1016/S1671-2927(07)60037-6

GÓMEZ-LÓPEZ, V. M., DEVLIEGHERE, F., RAGAERT, P., DEBEVERE, J. 2007. Shelf-life extension of minimally processed carrots by gaseous chlorine dioxide. International Journal of Food Microbiology, 116, 221-227. http://dx.doi.org/10.1016/j.ijfoodmicro.2006.12.008

GÓMEZ-LÓPEZ, V.M., RAGAERT, P., JEYACHCHANDRAN, V., DEBEVERE, J., DEVLIEGHERE, F. 2008. Shelf-life of minimally processed lettuce and cabbage treated with gaseous chlorine dioxide and cysteine. International Journal of Food Microbiology, 121, 74-83. http://dx.doi.org/10.1016/j.ijfoodmicro.2007.11.036

FDA. 2014. Secondary direct food additives permitted in food for human consumption, 21 CFR. Sec. 173. 300 Chlorine dioxide.

FU, Y., ZHANG, K., WANG, N., DU, J. 2007. Effects of aqueous chlorine dioxide treatment on polyphenol oxidases from Golden Delicious apple. $L W T$ Food Science and Technology, 40, 1362-1368. http://dx.doi.org/10.1016/j.lwt.2006.11.001

LI, H., LI, F., WANG, L., SHENG, J., XIN, Z., ZHAO, L., XIAO, H., ZHENG, Y., HU, Q. 2009. Effect of nano-packing on preservation quality of Chinese jujube (Ziziphus jujuba Mill. var. inermis (Bunge) Rehd). Food Chemistry, 114, 547-552. http://dx.doi.org/10.1016/j.foodchem.2008.09.085

MARTÍNEZ, G.A., CIVELLO, P.M. 2008. Effect of heat treatments on gene expression and enzyme activities associated to cell wall degradation in strawberry fruit. Postharvest Biology and Technology, 49, 38-45. http://dx.doi.org/10.1016/j.postharvbio.2008.01.013

NIELSEN, T., LEUFVÉN, A. 2008. The effect of modified atmosphere packaging on the quality of Honeoye and Korona strawberries. Food Chemistry, 107, 1053-1063. http://dx.doi.org/10.1016/j.foodchem.2007.09.025

POMBO, M.A., DOTTO, M.C., MARTÍNEZ, G.A., CIVELLO, P.M. 2009. UV$\mathrm{C}$ irradiation delays strawberry fruit softening and modifies the expression of genes involved in cell wall degradation. Postharvest Biology and Technology, 51, 141-148. http://dx.doi.org/10.1016/j.postharvbio.2008.07.007

SAHARI, M.A., BOOSTANI, F.M., HAMIDI, E.Z. 2004. Effect of low temperature on the ascorbic acid content and quality characteristics of frozen $\begin{array}{llll}\text { strawberry. } & \text { Food } & \text { Chemistry, } & \text { 86, }\end{array}$ http://dx.doi.org/10.1016/j.foodchem.2003.09.008 
SCHESTIBRATOV, K.A., DOLGOV, S.V. 2005. Transgenic strawberry plants expressing a thaumatin II gene demonstrate enhanced resistance to Botrytis cinerear Scientia Horticulturae, 177-189. http://dx.doi.org/10.1016/j.scienta.2005.03.016

SIMPSON, T., BIKOBA, V., MITCHAM, E.J. 2003. Effects of acetaldehyde on fruit quality and target pest mortality for harvested strawberries. Postharvest Biology and Technology, 28, 405-416. http://dx.doi.org/10.1016/S09255214(02)00206-5

SIMPSON, T., BIKOBA, V., MITCHAM, E. J. 2004. Effects of ethyl formate on fruit quality and target pest mortality for harvested strawberries. Postharvest $\begin{array}{llll}\text { Biology and } & \text { Technology, 313-319. }\end{array}$ http://dx.doi.org/10.1016/j.postharvbio.2004.05.015

TEREFE, N.S., MATTHIES, K., SIMONS, L., VERSTEEG, C. 2009. Combined high pressure-mild temperature processing for optimal retention of physical and nutritional quality of strawberries (Fragaria $\times$ ananassa). Innovative Food Science \& Emerging Technologies, $\quad 10, \quad 297-307$ http://dx.doi.org/10.1016/j.ifset.2008.12.003

VICENTE, A.R., MARTÍNEZ, G.A., CIVELLO, P.M., CHAVES, A.R. 2002. Quality of heat-treated strawberry fruit during refrigerated storage. Postharvest Biology and Technology, 5, 59-71. http://dx.doi.org/10.1016/S09255214(01)00142-9

ZHENG, X.L., TIAN, S.P., XU, Y., LI, B.Q. 2005. Effects of exogenous oxalic acid on ripening and decay incidence in mango fruit during storage at controlled atmosphere. Journal of Fruit Science, 22, 351-355. http://dx.doi.org/10.3969/j.issn.1009-9980.2005.04.012

ZHENG, Y., WANG, S.Y., WANG, C.Y., ZHENG, W. 2007. Changes in strawberry phenolics, anthocyanins, and antioxidant capacity in response to high oxygen treatments. LWT - Food Science and Technology, 40, 49-57. http://dx.doi.org/10.1016/j.lwt.2005.08.013 